\title{
Serum GRP-78 Düzeyleri Tedaviden 3 Ay Sonrasında Halen Yüksek Seyretmektedir: Bir Kohort Çalışması
}

\author{
Ramazan SABIRLI ${ }^{1}$, Aylin KÖSELER ${ }^{2}$, Tarık GÖREN ${ }^{3}$, Aykut KEMANCI $^{3}$, \\ Neslihan TÜRKÇÜER ${ }^{4}$, İbrahim TÜRKÇÜER ${ }^{3}$, Özgür KURT ${ }^{5}$ \\ 1 Kafkas Üniversitesi Tıp Fakültesi, Acil Tıp Anabilim Dalı, Kars. \\ 2 Pamukkale Üniversitesi Tıp Fakültesi, Biyofizik Anabilim Dalı, Denizli. \\ 3 Pamukkale Üniversitesi Tıp Fakültesi, Tıp Fakültesi Acil Tıp Anabilim Dalı, Denizli. \\ $4 \quad$ Pamukkale Üniversitesi Sağlık Bilimleri Fakültesi. Denizli. \\ 5 Acıbadem Mehmet Ali Aydınlar Üniversitesi Tıp Fakültesi, Mikrobiyoloji Anabilim Dalı, İstanbul.
}

\section{ÖZET}

GRP-78 proteininin bat koronavirüs, Mers-Cov, ebola virüs, deng virüsü, japon ensefalit virüsü, influenza virüs ve zika virüs gibi birçok virüsün hücreye girişinde rol oynadığı bilinmektedir. Bu çalışmada COVID-19 enfeksiyonu geçirmiş ve tedavi almış ve tamamen iyileşmiş olan hastalarda tedavi başlangıcından üç ay sonrasındaki Glucose Regulated Protein-78 (GRP-78) düzeylerini incelemeyi amaçladık. Daha öncesinde Sabırlı ve ark. tarafindan yapılan çalışma grubunda yer alan, COVID-19 hastalığı tanıs almış ve hastalığı geçirip tamamen iyileşmiş olan 20 hasta prospektif kohorta dahil edildi. Hastaların acil servise ilk tanıda başvurusu ve 3 ay sonra kontrole çağrıldığında alınan kanlardan enzyme-linked immunosorbent assay (ELISA) metodu ile GRP-78 düzeyi çalışıldı. Acil servise ilk başvuruda alınan kanda serum GRP-78 düzeyi 1393,31 $\pm 306,33 \mathrm{pg} / \mathrm{ml}$; tedavi başlangıcından 90 gün sonra bakılan serum GRP-78 düzeyi ise 1451,73 \pm 336,65 pg/ml olarak saptandı. İlk başvuru ve 3 ay sonraki kontrolde ölçülen GRP-78 düzeyleri açısından istatistiksel olarak anlamlı farklılık saptanmadı $(\mathrm{p}=0,451)$. Sonuç olarak bu çalışmada COVID-19 infeksiyonunda tedavi başlangıcından 3 ay sonrasında dahi yüksek seyrettiğini ortaya koyduk. GRP-78 düzeyinin yüksek kalmasının kişinin Sars-CoV-2 virüsüne karşı immunitesi konusunda fikir verdirici olabilir fakat bu hususun gerek hücre kültürü çalışması ve gerekse daha uzun süreli kohort çalışması yapılarak incelenmesine ihtiyaç vardır.

Anahtar Kelimeler: Endoplazmik Retikulum Stresi. GRP-78. COVID- 19 enfeksiyonu. Pnömoni.

Serum GRP-78 Levels Still Remain High 3 Months Later After the Treatment: A Cohort Study

\begin{abstract}
Glucose Regulated Protein (GRP-78) plays a role in the intrusion of many viruses such as bat coronavirus, MERS-CoV, ebola virus, dengue virus, Japanese encephalitis virus, influenza virus, and Zika virus. This study, however, aims to examine the GRP-78 levels in patients who were infected with COVID-19, treated and recovered completely three months after the initiation of treatment. A total of 20 patients who were diagnosed with the COVID-19 disease and fully recovered, and who had participated in a previous study conducted by Sabirlı et al., were included in this prospective cohort study. Using the enzyme-linked immunosorbent assay (ELISA) method, the GRP-78 levels were examined in the blood samples. The mean serum GRP-78 level was found to be $1393.31 \pm 306.33 \mathrm{pg} / \mathrm{ml}$ in the blood samples drawn from the patients when they were first admitted to the emergency department while the mean serum GRP-78 level measured 90 days after the initiation of treatment was $1451.73 \pm 336.65 \mathrm{pg} / \mathrm{ml}$. No statistically significant differences were found between the GRP-78 levels measured during the first admission and the follow-up control 3 months later $(\mathrm{p}=0.451)$. In conclusion, this study revealed that the GRP-78 levels remained high in patients with COVID-19 infections even after 3 months following the initiation of treatment. This high GRP-78 level may provide insight into the immunity of the person against the Sars-CoV-2 virus; however, this issue should be further examined both in a cell culture study and in a longer-term cohort study.
\end{abstract}

Key Words: Endoplasmic Reticulum Stress. GRP-78. COVID-19 infection. Pneumonia.

Geliş Tarihi: 12. Ocak.2021

Kabul Tarihi: 12.Şubat.2021

Dr. Aylin KÖSELER

Pamukkale Üniversitesi Tıp Fakültesi,

Biyofizik Anabilim Dalı,

Denizli.

Tel: +90 5336122477

E-posta: aylinkoseler@gmail.com
Yazarların ORCID Numaraları

Ramazan SABIRLI: 0000-0003-4599-5833

Aylin KÖSELER: 0000-0003-4832-0436

Tarık GÖREN: 0000-0002-8292-6717

Aykut KEMANCl:0000-0002-6308-3830

Neslihan TÜRKÇÜER: 0000-0002-2029-8751

İbrahim TÜRKÇÜER: 0000-0001-8342-4615

Özgür KURT: 0000-0001-5575-588X 
2019 yılının sonlarında Çin'de ortaya çıkan yeni tip koronavirüsün etken olduğu (SARS-CoV-2) COVID19 enfeksiyonu daha sonrasında tüm dünya çapında yayılmış ve Dünya Sağlık Örgütü (WHO) tarafından 11 Mart 2020 tarihinde global pandemi halini almıştır ${ }^{1}$. Damlacık yoluyla insandan insana bulaşan COVID-19 enfeksiyonu asemptomatik olarak geçebilmekle birlikte semptomatik hastalarda üst solunum yolu enfeksiyonu kliniğinden pnömoni, akut respiratuvar distress sendromu (ARDS), sepsis ve septik şok gibi ciddi klinik durumlara yol açmaktadır ${ }^{2}$.

Koronavirüslerin infektivitesinde spike proteinleri önemli rol oynamaktadır. Virüs Spike proteininin (S) hücre yüzeyi reseptörüne bağlanması koronavirüs enfeksiyonunu başlatmaktadır. COVID-19 enfeksiyonuna yol açan SARS-CoV-2 virüsü hücre içine reseptör aracılı endositoz mekanizmasıyla giren, zarflı ve tek sarmallı bir RNA virüsüdür ${ }^{3-6}$.

Glucose Regulated Protein 78 (GRP-78) proteini başlıca endoplazmik retikulum (ER) lümeninde bulunmakla birlikte, hücre yüzeyinde, sitozolde, mikonodride ve nükleusta da bulunan ER stres regülasyonunda rol oynayan en önemli şaperon proteinlerindendir ${ }^{7}$. ER stresi ortaya çıktığında GRP-78 ekspresyonu artışı olduğu ve ER'dan hücre membranına translokasyon gösterdiği saptanmıştır ${ }^{8}$.

GRP-78 proteininin bat koronavirüs, Mers-Cov, ebola virüs, deng virüsü, japon ensefalit virüsü, influenza virüs ve zika virüs gibi birçok virüsün hücreye girişinde rol oynadığ 1 bilinmektedir ${ }^{9}$. SARS-CoV-2 virüs enfeksiyonunda GRP-78 protein ekspresyonunda ve serum GRP-78 düzeyinde artış olduğu daha önceki çalışmalarda saptanmıştır ${ }^{10-12}$.

Bu çalışmada ise COVID-19 enfeksiyonu geçirmiş ve tedavi almış ve tamamen iyileşmiş olan hastalarda tedavi başlangıcından üç ay sonrasındaki GRP-78 düzeylerini incelemeyi amaçladık.

\section{Gereç ve Yöntem}

\section{Çalışma Tipi}

Çalışma bir prospektif kohort çalışması olup çalışmaya başlamadan önce Pamukkale Üniversitesi Tıp Fakültesi Girişimsel Olmayan Klinik Araştırmalar Etik Kurulu'ndan 08.12.2020 tarih ve 23 numaralı onay alınmıştır. Çalışmanın yapılması Sağlık Bakanlığı'nca uygun görülmüştür (28.11.2020).

\section{Hasta Popülasyonu}

Daha öncesinde Sabırlı ve ark. ${ }^{12}$ tarafindan yapılan çalışma grubunda yer alan, acil servise başvurmuş ve COVID-19 hastalığı tanısı almış, hiçbir ilaç kullanmayan, herhangi bilinen bir hastalığı olmayan, dönemin güncel kılavuzuna ${ }^{13}$ göre 5 gün favipiravir, hidroksiklorokin, düşük molekül ağırlıklı heparin ve parasetamol tedavisinin tamamını birlikte alan, çalışmaya katılmak için yazılı onamı olan, pnömoni tanısı olmayan yetişkin hastalar ile pnömonisi olup azitromisin tedavisi alan yetişkin hastalar prospektif kohorta dahil edildi. Hastaların tedavi başlangıcından 90 gün süre içinde tekrar hastaneye başvuru yapıp yapmadığı, başka bir enfeksiyon geçirip geçirmediği takip edildi. Doksan gün sonrasında hastadan tekrar laboratuvar parametresi bakılmak üzere çağrıldı ve kan alındı, vital parametreleri ölçüldü (ateş, nabız, oksijen saturasyonu, sistolik ve diyastolik kan basınc1).

\section{Dahil edilme kriterleri}

- Daha önce Sabırlı ve ark. ${ }^{12}$ tarafindan yapılan çalışmaya dahil olmak.

- Herhangi bilinen başka bir hastalığı olmamak.

- Herhangi bir ilaç kullanmamak (tedavi bitişi sonrası ve tedavi başlangıcı öncesinde).

- COVID-19 enfeksiyonu sonrasında 90 sürede herhangi bir enfeksiyöz hastalık geçirmemiş olmak.

- COVID-19 enfeksiyonu sonrasında 90 sürede herhangi bir sebeple hastane başvurusu olmamak.

- Çalışmaya katılmaya yazılı onam vermek.

- On sekiz yaş üzeri olmak.

\section{Dışlama kriterleri}

- Bilinen bir ilaç kullanımı veya hastalığın olması

- On sekiz yaş altı olmak

- COVID-19 enfeksiyonu sonrasında 90 sürede herhangi bir enfeksiyöz hastalık geçirmiş olmak.

- COVID-19 enfeksiyonu sonrasinda 90 sürede herhangi bir sebeple hastaneye başvurmuş olmak.

- Çalışmaya devam etmek istememek.

Çalışma grubunda yer alan ve COVID-19 enfeksiyonu tanılı 72 hastanın 15 tanesi komorbid hastalığı var olduğu için, 27'si çalışmaya devam etmek istemedikleri için, 10'u ise takip sürecinde enfeksiyöz sebepler dolayısıyla tekrar hastaneye başvurdukları için çalışma grubundan çıkartıldı. Toplamda 20 hasta prospektif kohorta dahil edildi.

\section{Kan Örneği Alınması ve Laboratuvar Parametreleri}

Acil servise başvuru sırasında rutin olarak bakılan tam kan sayımı, C reaktif protein (CRP), d-dimer, ferritin parametreleri data setine kaydedildi. GRP-78 düzeyi ölçümü için 3 cc kan örneği kuru tüpe alınarak 5000 rpm hızda 10 dakika santrifüj edildikten sonra serum kısmı ayrılarak Enzyme-Linked Immunosorbent Assay (ELISA) metoduyla GRP-78 düzeyi çalışıldı.

Hastalar tedavi başlangıcından 3 ay sonra tekrar çağrıldığında 5 cc kan kuru tüpe, 3 cc kan da EDTA'lı tüpe alınarak GRP-78 düzeyi, tam kan sayımı ve CRP düzeyi aynı metodlarla çalışıldı. Hastadan acil serviste tetkik amaçlı istenen laboratuvar parametreleri data setine kaydedildi. 


\section{COVID-19 Hastalığında Serum GRP-78 Düzeyleri}

\section{Serum GRP-78 Düzeyi Ölçümü}

Serum GRP78 düzeyi piyasada hazır olan uygun ELISA kiti ile (Human Glucose Regulated Protein 78(GRP78) ELISA Kit, Sun Long, SL2048Hu, China), üreticinin önerdiği protokol doğrultusunda çalışıldı. Bu kitin saptama sınırı 16pg/ml'idi.

\section{İstatistiksel Analiz}

Benzer olarak düzenlenmiş referans bir çalışma olmadığından, varsayımlar doğrultusunda yapılan güç analizi sonucunda, çalışmadan beklediğimiz etki büyüklüğünün orta-yüksek düzey olacağ $(\mathrm{f}=0.8)$ varsayıld1ğında $\% 95$ güvenle $\% 90$ güç elde edebilmek için çalışmaya en az 19 kişi alınması gerekli olduğu saptandı. Veriler SPSS paket programıyla analiz edildi. Sürekli değişkenler ortalama \pm standart sapma, medyan (IQR) olarak; kategorik değişkenler ise sayı ve yüzde olarak verildi. Sürekli verilerin parametrik dağılımının değerlendirilmesinde Kolmogrov Smirnov analizi uyguland. Bağımlı ve parametrik dağılım gösteren verilerin karşılaştırılmasında paired samples $\mathrm{t}$ test; bağımlı ve nonparametrik verilerin karşılaştırılmasında ise wilcoxon işaretli sıra testi uygulandı. Tüm incelemelerde $\mathrm{p}<0.05$ istatistiksel olarak anlamlı kabul edildi.

\section{Bulgular}

Çalışmaya dahil edilen hastalardan 11'i (\%55) erkek; 9'u (\%45) ise kadındı. Çalışma grubunun yaş ortala- mas1 36,45 $\pm 6,5$ yıl olarak saptandi. Hastaların 8 (\%40)'i COVID-19 pnömonisi tanısına sahipti. Acil servise ilk başvurudaki vital (ateş, oksijen saturasyonu, sistolik ve diyastolik kan basinc1) parametrelerine bakıldığında; ateş ortalaması $36,75 \pm 0,48{ }^{\circ} \mathrm{C}$; $\mathrm{sPO} 2$ 96,45 $\pm 1,6$; sistolik kan basinc1 119 $\pm 12,52 \mathrm{mmHg}$; diyastolik kan basinc1 ortalamas1 ise 76,5 $\pm 10,01$ $\mathrm{mmHg}$ olarak saptandı. Medyan semptom süresi ise 3 (2-6,5) gün olarak saptandı (Tablo I).

Acil servise ilk başvuruda alınan kanda serum GRP78 düzeyi 1393,31 $\pm 306,33 \mathrm{pg} / \mathrm{ml}$; tedavi başlangıcından 90 gün sonra bakılan serum GRP-78 düzeyi ise $1451,73 \pm 336,65 \mathrm{pg} / \mathrm{ml}$ olarak saptandı. İlk başvuru ve 3 ay sonraki kontrolde ölçülen GRP-78 düzeyleri açısından istatistiksel olarak anlamlı farklılık saptanmad1 $(\mathrm{p}=0,451)$ (Tablo II).

Hastaların ilk başvuru ve 3 ay sonraki kontrolde ölçülen diğer laboratuvar parametrelerine bakıldığında; tam kan sayımında lenfosit sayısı ilk ölçümde

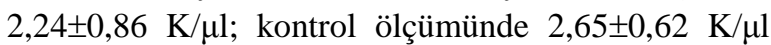
olarak sapandı. Serum CRP düzeyi ise ilk ölçümde 1,77 (0,65-13,24) mg/l; kontrol ölçümünde 0,95 (0,472) $\mathrm{mg} / \mathrm{l}$ olarak saptandi. Laboratuvar parametrelerinden sadece lenfosit sayısı kontrol ölçümde ilk ölçüme göre yüksek saptanırken; CRP düzeyi kontrol ölçümde ilk ölçüme göre istatistiksel olarak anlamlı şekilde düşük saptanmıştır (sırasıyla $\mathrm{p}=0,034$ ve $\mathrm{p}=0,032$ ) (Tablo III).

Tablo I. Çalışma grubunda bazal sosyodemografik ve vital bulgu verileri

\begin{tabular}{|c|c|c|c|}
\hline Cinsiyet, sayı (\%) & $\begin{array}{l}\text { Erkek } \\
\text { Kadın }\end{array}$ & \multicolumn{2}{|c|}{$11(\% 55)$} \\
\hline \multirow{3}{*}{ Pnömoni tanısı (\%) } & Var & \multicolumn{2}{|c|}{$8(\% 40)$} \\
\hline & Yok & & \\
\hline & & Ort. $\pm S S$ & $\begin{array}{c}\text { Medyan } \\
\text { (25-75. Çeyrekler) }\end{array}$ \\
\hline Yaş (YII) & & $36,45 \pm 6,5$ & $36,5(32-41)$ \\
\hline Semptom Süresi (Gün) & & $4,75 \pm 4,98$ & $3(2-6,5)$ \\
\hline Ateş $\left({ }^{\circ} \mathrm{C}\right)$ & & $36,75 \pm 0,48$ & $36,6(36,35-37)$ \\
\hline $\mathrm{SPO}_{2}$ & & $96,45 \pm 1,6$ & $96(95-98)$ \\
\hline Sistolik KB (mmHg) & & $119 \pm 12,52$ & $115(110-127,5)$ \\
\hline Diyastolik KB (mmHg) & & $76,5 \pm 10,01$ & $80(70-80)$ \\
\hline
\end{tabular}

Ort; ortalama, SS; Standart sapma, KB; kan basıncı,

Tablo II. Çalışma grubunda serum GRP-78 düzeyleri

\begin{tabular}{|c|c|c|c|c|c|}
\hline & \multicolumn{2}{|c|}{ Çalışma Başlangıcı } & \multicolumn{2}{|c|}{3 Ay Sonra } & \multirow[t]{2}{*}{ p Değeri } \\
\hline & Ort $\pm S S$ & $\begin{array}{c}\text { Medyan } \\
\text { (25-75. Çeyrekler) }\end{array}$ & Ort $\pm S S$ & $\begin{array}{c}\text { Medyan } \\
\text { (25-75. Çeyrekler) }\end{array}$ & \\
\hline GRP-78 (pg/ml) & $1393,31 \pm 306,33$ & $\begin{array}{c}1407.59 \\
(1195,32-1452,93)\end{array}$ & $1451,73 \pm 336.65$ & $\begin{array}{c}1392,5 \\
(1220,41-1656) \\
\end{array}$ & 0,451 \\
\hline
\end{tabular}

*p- değeri bağımlı gruplarda t testinden elde edilmiștir.

GRP-78; Glucose regulated protein 78, Ort; Ortalama, SS; Standard sapma. 
Tablo III. Çalışma Grubunda Laboratuvar Parametreleri

\begin{tabular}{|c|c|c|c|c|c|}
\hline & \multicolumn{2}{|c|}{ Çalışma Başlangıcı } & \multicolumn{2}{|c|}{3 Ay Sonra } & \multirow[t]{2}{*}{$p$ Değer } \\
\hline & Ort $\pm S S$ & $\begin{array}{c}\text { Medyan } \\
\text { (25-75. Çeyrekler) }\end{array}$ & Ort $\pm S S$ & $\begin{array}{c}\text { Medyan } \\
\text { (25-75. Çeyrekler) }\end{array}$ & \\
\hline WBC $(\mathrm{K} / \mu \mathrm{l})$ & $8,46 \pm 3,72$ & $8,28(5,57-11,03)$ & $8,29 \pm 2,18$ & $7,99(6,77-9,21)$ & 0,791 \\
\hline Hemoglobin (g/dl) & $13,77 \pm 2,12$ & $13,85(12,27-15,4)$ & $13,88 \pm 2: 05$ & $14,2(12,12-15,67)$ & 0,702 \\
\hline 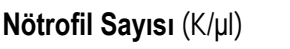 & $5,44 \pm 3,51$ & $4,22(3,21-7,75)$ & $4,79 \pm 1,5$ & $4,48(3,77-5,45)$ & 0,322 \\
\hline 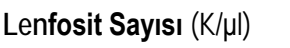 & $2,24 \pm 0,86$ & $2,01(1,5-2,92)$ & $2,65 \pm 0,62$ & $2,54(2,28-3,12)$ & 0,034 \\
\hline Trombosit Sayısı $(K / \mu l)$ & $250,15 \pm 85,99$ & $262,5(198,5-310,75)$ & $262,35 \pm 70,39$ & $271(218,75-302,5)$ & 0,355 \\
\hline C-Reaktif Protein (mg/l) & $14,17 \pm 33,12$ & $1,77(0,65-13,24)$ & $1,35 \pm 1,13$ & $0,95(0,47-2)$ & $* 0,032$ \\
\hline D-Dimer (ng/mL) & $138,73 \pm 91,34$ & 101 (61-201) & & & \\
\hline Ferritin (ug/L) & $199,02 \pm 357,62$ & $54,28(19,18-238)$ & & & \\
\hline hsTnT ( $\mu \mathrm{g} / \mathrm{l})$ & $3,18 \pm 0,37$ & $3(3-3,16)$ & & & \\
\hline
\end{tabular}

$p$-değerleri bağımlı gruplarda $t$ testinden elde edilmiştir.

WBC; Beyaz küre sayısı, hsTnT; high sensitif troponin t, Ort; Ortalama, SS; Standart sapma.

Tablo IV. Çalışma alt gruplarında serum GRP-78 düzeyleri

\begin{tabular}{|c|c|c|c|c|c|c|}
\hline \multirow{4}{*}{$\begin{array}{l}\text { GRP-78 } \\
\text { (pg/ml) }\end{array}$} & & \multicolumn{2}{|c|}{$\begin{array}{l}\text { Covid-19 Pnömonisi } \\
\qquad(\mathrm{N}=8)\end{array}$} & \multicolumn{2}{|c|}{$\begin{array}{l}\text { BT Negatif Covid-19 Enfeksiyonu } \\
\qquad(\mathrm{N}=12)\end{array}$} & \multirow[t]{2}{*}{$p$ Değeri } \\
\hline & & Ort. \pm SS & $\begin{array}{l}\text { Medyan } \\
\text { (25-75. Çeyrekler) }\end{array}$ & Ort. \pm SS & $\begin{array}{l}\text { Medyan } \\
\text { (25-75. Çeyrekler) }\end{array}$ & \\
\hline & Çalışma Başlangıcı & $1396,54 \pm 154,38$ & $\begin{array}{l}1446,94 \\
(1250,13-1482,52)\end{array}$ & $1391,17 \pm 383,29$ & $\begin{array}{l}1289,52 \\
(1102-1552,25)\end{array}$ & \multirow{2}{*}{$\begin{array}{l}{ }^{1} p=0,036 \\
{ }^{2} p=0,875 \\
{ }^{3} p=0,27 \\
{ }^{4} p=0,115\end{array}$} \\
\hline & 3 Ay Sonra & $1549,28 \pm 204,02$ & $\begin{array}{l}1274,32 \\
(1178,65-1444,3)\end{array}$ & $1386,8 \pm 397,2$ & & \\
\hline
\end{tabular}

${ }^{1} p$ değeri Wilcoxon İşaretli Sira testinden elde edilmiştir ve Covid-19 pnömoni alt grubunda başlangıç ve 3. Ay GRP-78 düzeylerinin istatistiksel analizini ifade etmektedir.

${ }^{2} p$ değeri Wilcoxon İşaretli Sıra testinden elde edilmiştir ve BT (-) Covid-19 enfeksiyonu alt grubunda başlangıç ve 3. Ay GRP-78 düzeylerinin istatistiksel analizini ifade etmektedir.

${ }^{3} p$ değeri Mann Whitney U testinden elde edilmiştir ve Covid-19 pnömonisi olan ve olmayan grupların çalışma başlangıcındaki serum GRP78 düzeyinin istatistiksel analizini ifade etmektedir.

${ }^{4} p$ değeri Mann Whitney U testinden elde edilmiştir ve Covid-19 pnömonisi olan ve olmayan grupların 3. aydaki serum GRP-78 düzeyinin istatistiksel analizini ifade etmektedir.

Ort; Ortalama, SS; Standard sapma, GRP78, Glucose Regulated Protein 78

Çalışma grubu COVID-19 pnömonisi ve BT (-) COVID-19 enfeksiyonu alt gruplarına ayrıldığında her iki grubun GRP-78 düzeyleri açısından hem başlangıç hem de 90 gün sonraki ölçümde istatistiksel olarak anlamlı farklılık olmadığ ${ }_{1}$ saptandı (sırasıyla $\mathrm{p}=0,27$ ve $\mathrm{p}=0,115$ ). COVID-19 pnömonisi olan hastalarda kontrol GRP-78 düzeyinde başlangıçta ölçülen düzeye göre istatistiksel olarak anlamlı düşüş gözlenmişken; BT (-) Covid enfeksiyonu grubunda önceki ve sonraki ölçümler arasında istatistiksel olarak anlamlı değişim saptanmadi (sırasiyla $\mathrm{p}=0,036$ ve $\mathrm{p}=0,875$ ) (Tablo IV).

\section{Tartışma ve Sonuç}

Viral enfeksiyonlarda ER stresi ortaya çıktığında GRP-78 protein aşırı salınımının olduğu ve ER'dan hücre membranına geçiş gösterdiği saptananmıştır ve GRP-78 yarasa coronavirüsü, mers-Cov, ebola virüs, dengue virüs, japon ensefalit virüsü, influenza virüs ve
Zika virüs gibi birçok virüsün hücreye girişinde rol oynamaktadır. Ayrıca SARS-CoV enfeksiyonunda GRP-78 salınımında artış olduğu gösterilmiştir ${ }^{9,14}$. Versteeg ve arkadaşları tarafindan yapılan çalışmada MHV ve SARS-CoV enfeksiyonlarının ER stresini indüklediği ortaya konmuştur ${ }^{15}$. Farelerde sepsis modeli oluşturularak yapılan bir çalışmada septik farelerde serum GRP-78 düzeyinin kontrol grubuna göre yüksek olduğu saptanmış ve GRP-78'in sepsis için bir biyobelirteç olarak kullanılabileceği öne sürülmüştür ${ }^{16}$. Yine sepsis üzerine yapılan bir başka çalışmada ise yüksek GRP-78 gen ekspresyonu olan hastalarda yoğun bakım kötü klinik gidiş ile korele olarak saptanmıştır ${ }^{17}$. Sabırlı ve arkadaşları tarafindan yapılan çalışmada gerek COVID-19 pnömonisinde gerekse BT (-) COVID-19 enfeksiyonunda serum GRP-78 düzeyinin kontrol grubuna göre yüksek olduğu saptanmış$\operatorname{tır}^{10,12}$. Hücre kültüründe yapılan bir çalışmada GRP78 proteinin interferon beta aracilı bir mekanizma ile anti-HBV faktör gibi işlev gördüğü gösterilmiştir ${ }^{18}$. 


\section{COVID-19 Hastalığında Serum GRP-78 Düzeyleri}

GRP-78 düzeylerinin gerek COVID-19 enfeksiyonu ve pnömonisinde, gerekse sepsis hastalarında yükseldiği gösterilmiş olsa da bu durumun ne kadar devam ettiğine dair bir literatür verisine rastlamadık.

Her ne kadar ilk başvurudaki düzeyle benzer sonuçlar bulsak da daha önceki çalışmamızda sağlam popülasyonda saptadığımı GRP-78 düzeylerine göre 3 ay sonraki ölçülen GRPP-78 düzeyi belirgin olarak yüksektir. Çalışmamızda ise 3 ay sonra hastaların serum GRP-78 düzeyleri ile ilk başvuru tarihindeki düzeylerine benzer şekilde yüksek olmasının enfeksiyon sona erse de hücrede ER stresin devam ettiğini göstermektedir. Hepatit B enfeksiyonundakine benzer şekilde Sars-CoV-2 virüsü ile ER stresin tetiklenmesi sonrasinda enfeksiyon sona erse de GRP-78 proteini yine interferon aracılı bir mekanizma ile antiviral faktör olarak etki gösteriyor olabilir. Bu durum ayrıca GRP78 yüksekliğinin sürmesinin immun yanıtın sürmekte olduğuna işaret edebileceğini de düşündürmektedir. Her ne kadar bu durum paradoks gibi görünse de immun yanıtın devamlılığında GRP-78 proteininin rolü daha geniş bir çalışmada araştırılmalıdır.

COVID-19 pnömonisi geçiren hastalarda 3 ay sonrasında serum GRP-78 düzeyindeki düşüş her ne kadar istatistiksel olarak anlamlı görünse de hasta popülasyonu çok küçük olduğu için hastaların bireysel immunite farklılığı sebepli mi, kullanılan antibiyotik sebepli mi yoksa tesadüfen bir düşüş mü olduğu konusunda bir yargıya varılması mümkün değildir. $\mathrm{Bu}$ hususta daha büyük COVID-19 pnömoni popülasyonunda çalışma yapılmasına ihtiyaç vardır.

Çalışmamızın bazı kısıtlılıkları mevcuttur. COVID-19 hastalarından akciğer dokusu veya bronkoalveolar lavaj sıvısı örneği alınmamış olması ve doku örneğinden GRP-78 düzeyi çalışılmamış olması önemli bir kısıtlılıktır fakat hastalığın bulaş riski sebebiyle periferik kandan örnek çalıșılması tercih edilmiștir. Ayrıca GRP-78 düzeylerinin ne kadar süre yüksek kaldığına dair bir literatür verisi mevcut değildir (invivo ortamda). Ayrıca hastaların COVID-19 immunglobulin düzeylerinin ölçülmemiş olması da çalıșmamızın kısıtlılıklarındandır. Daha geniș bir çalıșma popülasyonunda bu çalışmanın yapılması daha değerli sonuçlar ortaya çıkabilecektir.

Sonuç olarak bu çalışmada COVID-19 infeksiyonunda tedavi başlangıcından 3 ay sonrasında dahi yüksek seyrettiğini ortaya koyduk. GRP-78 düzeyinin yüksek kalmasının kişinin Sars-CoV-2 virüsüne karşı immunitesi konusunda fikir verdirici olabilir fakat bu hususun gerek hücre kültürü çalışması ve gerekse daha uzun süreli kohort çalışması yapılarak incelenmesine ihtiyaç vardır.

Etik Kurul Onay Bilgisi:

Onaylayan Kurul: Pamukkale Üniversitesi Tıp Fakültesi Girișimsel Olmayan Klinik Araștırmalar Etik Kurulu.

Onay Tarihi: 08.12.2020

Karar No: 23
Araştırmacı Katkı Beyanı:

Fikir ve Tasarım: Ay.Kö.,R.S.,İT.,Ö. K.; Veri toplama ve ișleme: T.G.,Ay.Ke.,N.T.; Analiz ve verilerin yorumlanması: İ.T., Ay.Kö., T.G., N.T.; Makalenin önemli bölümlerinin yazılması: R.S., Ö.K., Ay.Ke.

Destek ve Teşekkür Beyanı:

Makale yazarlarının destek ve teșekkür beyanı yoktur.

Çıkar Çatışması Beyanı:

Makale yazarlarının çıkar çatışması beyanı yoktur.

\section{Kaynaklar}

1. CDC. 2019 Novel Coronavirus, Wuhan, China. CDC. Available at https://www.cdc.gov/coronavirus/2019ncov/about/index.html. January 26, 2020; Accessed: January 27, 2020. Gallegos A. WHO Declares Public Health Emergency for Novel Coronavirus. Medscape Medical News. Available at https://www.medscape.com/viewarticle/924596. January 30, 2020; Son Erişim Tarihi:1 Aralık, 2020.)

2. Cascella M, Rajnik M, Cuomo A, et al. Features, Evaluation, and Treatment of Coronavirus (COVID-19) [Updated 2020 Aug 10]. In: StatPearls [Internet]. Treasure Island (FL): StatPearls Publishing; 2020 Jan-. Available from: https://www.ncbi.nlm.nih.gov/books/NBK554776/

3. Coronaviridae Study Group of the International Committee on Taxonomy of Viruses. The species Severe acute respiratory syndrome-related coronavirus: Classifying 2019-nCoV and naming it SARS-CoV-2. Nat. Microbiol 2020;5: 536-44.

4. Huang Y, Yang C, Xu XF, Xu W, Liu SW. Structural and functional properties of SARS-CoV-2 spike protein: potential antivirus drug development for COVID-19. Acta Pharmacol Sin 2020;41:1141-9.

5. Kuo L, Godeke GJ, Raamsman MJ, Masters PS, Rottier PJ. Retargeting of coronavirus by substitution of the spike glycoprotein ectodomain: crossing the host cell species barrier. J Virol 2000;74: 1393-1406.

6. Yamada Y, Liu XB, Fang SG, Tay FP, Liu DX. Acquisition of cell-cell fusion activity by amino acid substitutions in spike protein determines the infectivity of a coronavirus in cultured cells. PLoS One 2009;4:e6130.

7. Zhang Y, Liu R, Ni M, Gill P, Lee AS. Cell surface relocalization of the endoplasmic reticulum chaperone and unfolded protein response regulator GRP78/BiP. J Biol Chem 2010;14;285:15065-75.

8. Ibrahim IM, Abdelmalek DH, Elfiky AA. GRP78: A cell's response to stress. Life Sci 2019;226:156-63.

9. Chu H, Chan CM, Zhang X, et al. Middle East respiratory syndrome coronavirus and bat coronavirus HKU9 both can utilize GRP78 for attachment onto host cells. J J Biol Chem. 2018;293:11709-26.

10. Köseler A, Sabirli R, Gören T, Türkçüer I, Kurt Ö. Endoplasmic Reticulum Stress Markers in SARS-COV-2 Infection and Pneumonia: Case-Control Study. In Vivo 2020;34:1645-50.

11. Palmeira A, Sousa E, Köseler A, et al. Preliminary Virtual Screening Studies to Identify GRP78 Inhibitors Which May Interfere with SARS-CoV-2 Infection. Pharmaceuticals (Basel) 2020;13:132.

12. Sabirli R, Koseler A, Goren T, Turkcuer I, Kurt O. High GRP78 levels in COVID-19 infection: A case-control study. Life Sci 2021;265:118781.

13. https://covid19.saglik.gov.tr/Eklenti/39061/0/covid19rehberieri skinhastatedavisipdf.pdf. (Son Erişim Tarihi:11.12.2020)

14. Chan CP, Siu KL, Chin KT, Yuen KY, Zheng B, Jin DY. Modulation of the unfolded protein response by the severe acute respiratory syndrome coronavirus spike protein. J Virol 2006;80:9279-87.

15. Versteeg GA, van de Nes PS, Bredenbeek PJ, Spaan WJ. The Coronavirus Spike Protein Induces Endoplasmic Reticulum Stress and Upregulation of Intracellular Chemokine mRNA Concentrations. J Virol 2007; 81: 10981-90. 
R. Sabırlı, ark.

16. Doerflinger $M$, Reljic B, Menassa J, et al. Circulating $\mathrm{BiP} / \mathrm{Grp78}$ is a novel prognostic marker for sepsis-mediated immune cell death. FEBS J. 2020 Sep 7. doi: 10.1111/febs.15552. Epub ahead of print. PMID: 32894892.

17. Stan RC, Pinto Bonin C, Porto R, Soriano FG, de Camargo MM. Increased grp78 transcription is correlated to reduced tlr4 transcription in patients surviving sepsis. Clin Exp Immunol 2019;198:273-80.

18. Ma Y, Yu J, Chan HL, et al. Glucose-regulated protein 78 is an intracellular antiviral factor against hepatitis B virus. Mol Cell Proteomics 2009;8:2582-94. 